\title{
EFFECTS OF ZINC, MANGANESE METHIONINE COMPLEX AS FEED, SUPPLEMENT ON THE YIELD, COMPOSITION AND QUALITY OF COW'S MILK AND ITS PRODUCTS. El-Nimer, Amal M. M.; M.A. Ahmed ${ }^{1}$; H. H. Omar ${ }^{1}$ and M. A. Y. El- menniawy ${ }^{2}$ \\ 1-Dairy Technology Department, Animal Production Research Institute, Agricultural Research Center, Dokki, Giza. Egypt. \\ 2-Utilization of by-Products Department, Animal Production Research Institute, Agricultural Research Center, Dokki, Giza, Egypt.
}

\begin{abstract}
Twelve Local breed lactating dairy cows in early lactation were selected to investigate the effect of feeding supplemented with a combination of organic trace minerals Zinc $(\mathrm{Zn})$ and manganese $(\mathrm{Mn})$ tied with methionine (Met.) on milk yield, its components, the gross chemical composition, $\mathrm{pH}$, rate of acid production, $\mathrm{Zn}$ and $\mathrm{Mn}$ concentrations and their activities on starter culture for processing plain yoghurt. Cows were randomly divided into four experimental groups ( 3 each) using $3 \times 3$ Latin Square design for 35 days periods. Treatments were: T1 (control): concentrate feed mixture $(60 \%$ CFM) + berseemhay $(20 \% \mathrm{BH})$ + rice straw $(20 \% \mathrm{RS})$, T2: control ration plus $40 \mathrm{mg}$ Zinc-Methionine/head /day, T3: control ration plus 40mg ManganeseMethionine/ head/ day, T4: control ration plus $20 \mathrm{mg} \mathrm{Zn}$ - Methionine plus $20 \mathrm{mg} \mathrm{Mn-}$ Methionine / head/ day (as total diet DM). Milk samples were collected daily from each cow morning and evening for the estimation of milk yield production. Pooled milk from each period was used in the manufacture of yoghurt. Yoghurt samples were stored at refrigerator $\left(6 \pm 1 \mathrm{C}^{\circ}\right)$ for 10 days. Results showed that the addition of organic minerals Zinc and Manganese -methionine to the cow diet significantly increased $(P<0.05)$ milk yield, milk fat percentage and $4 \%$ fat-corrected milk (FCM) compared with the control treatment. Also, fat, solids not fat (SNF), ash and total protein (TP) were significantly increased in treated group. Milk produced from cows fed on $\mathrm{Zn}$ - Methionine and MnMethionine did not significantly affect, Ts, Fat, protein and Ash of resultant plain yoghurt through the storage period. Reduction in $\mathrm{pH}$ values, lactose content and the rate of synersis with treated yoghurt samples compared to the control. Whereas, an opposite trend was noticed for acidity, curd tension. While, the concentrations of these organic trace minerals in different treatments of plain yoghurt increased, the ratio of $\mathrm{Mn}$ remained in the curd plain yoghurt was increased, and the ratio of remained $\mathrm{Zn}$ in the curd was decreased. Viscosity of fresh samples of both control and treatments were significantly increased then, significantly decreased till the end of storage. The incubation time was shorter in treated yoghurt with $\mathrm{Zn}$ Met. than the other treatments. The inhibition effect of $\mathrm{Zn}$ Met. on the yoghurt bacteria was stronger than those other treatments. Sensory properties values revealed that flavor, body and texture were significant increased with containing yoghurt $\mathrm{Zn}$ - methionine when compared with the other treatments.
\end{abstract}

\section{INTRODUCTION}

The benefits of supplementation organic trace minerals in dairy diets have been demonstrated in research and in the field of feeding. Traditionally in organic forms of trace minerals rapidly dissociation in the rumen and are free to interact with antagonists, resulting in the loss of the trace minerals 
prior to absorption by animal. However, in recent years, there has been considerable interest in feeding ruminants organic trace minerals that increase the bioavailability of the mineral above that of soluble inorganic forms (Ward et al., 1996; Miles and Henry, 1999; Bailey et al., 2001).

A metal amino acid (AA) complex results from complexing a soluble metal salt with an $A A$ in a ratio of $1 \mathrm{~mol}$ of metal to $1 \mathrm{~mol}$ of $A A$ to form coordinate covalent bonds. In addition to vitamin, protein and energy requirements the dairy cows also needs certain trace elements including Zinc and Manganese plus the microelements magnesium and Potassium for lactation and reproduction concurrent with growth and maintenance of body tissues (Zin et al., 1993).

Milk and its products are considered of the most important sources of nutrients for human diets along his life. However, milk is rich in lipids, proteins carbohydrates, and some minerals such as calcium, magnesium, phosphorus but it is poor in some other elements, particularly, zinc and iron (Jayasekar et al., 1992). Also, in this line Jarrstt (1979) reported that milk is considered to be deficient in zinc, therefore, consumers need to obtain their sufficient requirements of this trace element form products other than milk.

Yoghurt can be a good source of essential nutrients as minerals in the human diet. Mineral ions play an essential role in regulating enzyme activities, maintaining acid-base balance and osmotic pressure, facilitating membrane transfer of essential nutrients and maintaining nerve and muscular irritability (Achanta et al., 2007). Zinc is a component of many enzymes and biomembranes. It is involved binding many transcription factors and stabilizes hormone-receptor complexes.

Zinc deficiency is characterized by growth retardation, loss of appetite, impaired immune function, hair loss, diarrhea, impotence, hypogonadism in males, eye, skin lesions, delayed healing of wounds and impaired taste (Maret an Sandstead, 2006).

Manganese is involved in enzyme activation and is a component of several metallo enzymes.

Manganese deficiency causes impaired growth, skeletal abnormalities, disturbed or depressed reproductive function and defects in lipid and carbohydrate metabolism (Nielsen, 1994).

Yoghurt is considered as a good fermented dairy product for health, therefore, its production have become widely increased (Tamime and Death, 1980). Despite the importance of yoghurt as a fermented dairy product it is made as natural candidates as source of zinc in human diets. Dael et al., (1993). found that yield yoghurt significantly increased $\mathrm{Zn}$ availability (12.5\%) compared with raw milk (6.3\%).

The objective of this study aimed to the effect of supplement Zinc, Manganese- Methionine or both of them to the cows diet, on milk yield, its chemical composition and to detect the concentrations of $\mathrm{Zn}$ and $\mathrm{Mn}$ in plain yoghurt, whey and the effect of this minerals on, physicochemical characteristics, acid rate production and activity of starter culture in plain yoghurt and whey. 


\section{MATERIALS AND METHODS}

This study was carried out at Sids Animal production Research Station (Beni-Sweif Governorate) that belongs to Animal production Research Institute (APRI), Ministry of Agriculture, Egypt. Twelve Local breed Lactating dairy cows in early lactation were selected in this trail with an average $350.50 \mathrm{~kg}$ live boy weight. Cows were randomly divided into four experimental groups ( 3 each) using $3 \times 3$ Latin Square design for 35 days periods (105 days).

\section{The experimental treatment diets were as follows:}

Treatment (1) control: concentrate feed mixture (60\%CFM) berseemhay $(20 \% \mathrm{BH})+$ rice straw $(20 \% \mathrm{RS})$

Treatment (2) control ration plus 40mg Zinc Methionine/ head/ day.

Treatment (3) control ration plus plus 40mg Manganese Methionine/ head/ day.

Treatment (4) control ration plus 20mg Zinc Methionine $+20 \mathrm{mg}$ Manganese Methionine/ head/ day. Table (1).

The chemical composition of feed ingredients and diets are shown in

All cows were fed the same diets during the experiment: concentrate fed mixture (CFM), berseemhay (BH), rice straw (RS) and mineral-vitamin mixture. The daily rations of feed covered cows maintenance recommended requirements according to NRC (2001). and requirement for the production of $10 \mathrm{~kg}$ milk.

Daily diets was a mixed of CFM, BH and rice straw with $60 \%, 20 \%$ and $20 \%$ respectively, without supplement (Group 1) or supplemented with mineral mixtures which contained $\mathrm{Zn}$ and $\mathrm{Mn}$ in methionine forms given to the animals at a dose of $4 \mathrm{~g} /$ day/head (Group 2, 3, 4). Clean water was available at all time. Milk samples were taken daily from each cow evening and morning for estimation of milk yield. Pooled milk form each period was used in the manufacture of plain yoghurt.

\section{Manufacture of plain yoghurt:}

Yoghurt was manufactured according to Tamime and Robinson (1999). Control and treated milk produced from cows fed diets supplemented with different levels organic trace minerals $\mathrm{Zn}$ and $\mathrm{Mn}$ Met. Were separately heated in a water bath at $85 \mathrm{C}^{\circ}$ for $10 \mathrm{~min}$., cooled to $45 \mathrm{C}^{\circ}$ and inoculated with commercial yoghurt culture were added at the level of $2 \%(\mathrm{w} / \mathrm{v})$. The milk was divided to four portions as one control and three treatments, samples were incubated at $43 \mathrm{C}^{\circ}$ until $\mathrm{pH}$ of 4.7 was reached ( 3 hours fermentation time), the coagula was cooled and stored in a refrigerator at $4^{\circ} \mathrm{C}$ for one night. Yoghurt was mainly 1 day old then, it was drained to remove some whey using a cloth bag. The prepared yoghurt was kept in refrigerator $\left(6 \pm 1^{\circ} \mathrm{C}\right)$ for 10 days. Samples of yoghurt were analyzed when fresh and during 3,7 and 10 days of storage. 
Table (1): chemical composition of ingredients used in feeding trial (\% on DM basis).

\begin{tabular}{lccc}
\hline Item & CFM $^{*}$ & Berseem hay & Rice straw \\
\hline Dry matter & 92.09 & 91.3 & 91.81 \\
Organic matter & 88.20 & 84.10 & 91.51 \\
Crude fiber & 14.11 & 38.20 & 38.41 \\
Crude protein & 13.01 & 12.00 & 3.66 \\
Ash & 11.35 & 14.60 & 1.25 \\
EE & 1.44 & 1.03 & 11.55 \\
NFE & 60.09 & 34.17 & 45.13 \\
\hline
\end{tabular}

${ }^{*}$ CFM: contains per 3kg Vit. A1000000 IU; Vit. D3 200000 IU; Vit. E, 10000 mg

Vit. B1, $1000 \mathrm{mg}$; Vit. B2 $5000 \mathrm{mg}$; B6, $1500 \mathrm{mg}$; Vit. B121, $10 \mathrm{mg}$; Biotin, 50

$\mathrm{mg}$; Colin chloride, $250000 \mathrm{mg}$; Pentothenic, $10000 \mathrm{mg}$; Niacin, $30000 \mathrm{mg}$;

Folic acid, $1000 \mathrm{mg}$; Manganese, 60000 gm; Zink, 50000 mg; Iron, 3000 mg;

Copper, 4000 mg; lodine, 300 mg; Selenium, 100 mg; and, Cobalt, 100 mg.

Methods of analysis:

Chemical analysis:

Milk and yoghurt samples were analyzed for percentages of milk fat, total solids (TS), and ash contents and titralable acidity as described by ling (1963). Protein was determined according to A.O.A.C. "Official Methods of Analysis (2000)". lactose content was determined by the method of calorimetrically according to (Bernett and Abd El-Tawab 1957), using spectrophotometer at $490 \mathrm{~nm}$ wavelength type Shimadzu $\mu \mathrm{V} 240 . \mathrm{pH}$ values was measured using digital $\mathrm{pH}$ meter (M 41150, USA) equipped with glass electrodes.

Viscosity:

Apparent viscosity of yoghurt was measured using Brookfield DVE Viscometer, using spindle 0.5 at $50 \mathrm{rpm}$ in $200 \mathrm{ml}$ of yoghurt sample, the temperature was maintained at $25 \mathrm{C}^{\circ}$. data were collected using Wingather soft ware, one hundred data points were averaged per replication.

Rate of syneresis:

Syneresis (released whey) was measured by placing a $300 \mathrm{~g}$ yoghurt sample on a cheese cloth placed on top of a funnel. After $2 \mathrm{~h}$ of drainage, the volume of whey collected in a graduated cylinder was measured after 120 min. and used as an index of syneresis (Kalafalla \& Roushdy 1996).

Curd tension: of plain yoghurt. Was assessed by using Effagi firmness measurements (Effagi, Al bonsine, Italy). The penetration depth was $50 \mathrm{~mm}$ using a flat ended stainless steel plunger with diameter of $5 \mathrm{~mm}$. five readings were taken for each yoghurt treatment.

Incubation time:

The coagulation of inoculated milk with starter culture and the different ratios of organic minerals $\mathrm{Zn}$ and $\mathrm{Mn}$ Met. was measured for $\mathrm{pH}$ during the incubation period until pH 4.6 was attained.

Determination of $\mathrm{Zn}$ and $\mathrm{Mn}$ Met. concentrations in plain yoghurt and whey:

Data were measured by flame Atomic Absorption Spectrophotometer (Perkin Elmer 2380). Maximum absorbance was obtained by adjusting the cathode lamps at specific slit and wave lengths. Zn was measured at 319.9 
$\mathrm{nm}$, and $\mathrm{Mn}$ at $279 \mathrm{~nm}$. Standard $\mathrm{Zn}$ and $\mathrm{Mn}$ solution were fresh prepared from $1000 \mathrm{mg} / \mathrm{L}$ stock solution and a linear calibration curve was used.

The samples digestion in an electric muffle furnace at the temperature up to $450^{\circ} \mathrm{C}$.

The validity of this method was cheeked by a parallel analysis of certified reference material (CRM 063) Skimmed powder milk).

\section{Sensory evaluation:}

The sensory evaluation was done according to Kebary and Hussein (1999). By 15 panalists from the staff members of Dairy Technology and Dairy Science Department, Animal Production Research Institute (APRI). Samples were scored for flavour out of (50 points), body and texture out of (40 points) ,color and appearance (10 points).

\section{Statistical Analysis:}

Data were statistically analyzed on three replicates on the plain yoghurt and whey by using General Linear Model procedure of SAS program (1996) according to the following model:

$Y_{i j k} \ldots=\mu+T_{i}+S_{j}+T_{i j}+e_{i j k}$

Where:

$Y_{\mathrm{ijk}}=$ The observation, $\quad \mu=$ General mean,

$T_{i}=$ Fixed effect of $i^{\text {th }}$ Zinc and Manganese supplementation,

$i=1,2, \ldots 4, S_{j}=$ Fixed effect of $j^{\text {th }}$ storage period $(j=0,3,7$ and 10 days $)$

$\mathrm{TS}_{\mathrm{ij}}=$ the fixed effect of interaction between $\mathrm{Zn}$ and $\mathrm{Mn}$ supplementation and storage period, and $\mathrm{e}_{\mathrm{ijk}}=$ Error of the model. Significance of the differences in result tested by Duncan's new Multiple range test (Duncan, 1955).

\section{RESULTS AND DISCUSSION}

\section{Milk yield and composition:}

The yield and composition of milk used in plain yoghurt manufacture are presented in Table (2). Milk yield was not significantly affected by treatments. However, the $T_{2}$ treatment tended to increase milk yield at week 13 (37.7 \pm 0.8 compared with control $(35.1 \mathrm{P}=0.073)$ and increased milk yield at week $14(37.9+0.8$ compared with control $35.5 \mathrm{P}=0.032)$ of lactation, several results have been reported when dairy cows were supplemented with organic trace minerals (Formigoni et al., 1993) observed that an increase in average milk $(1.9 \mathrm{~kg} /$ day $\mathrm{P}<0.01)$, when cows fed supplemented feeds.

4\% Fat corrected Milk (FCM) was significantly increased $(P<0.05)$ for cows fed supplemented feeds with Zn-Met and Mn-Met. $(35.7 \pm 1.1 \mathrm{~kg} / \mathrm{d})$ compared with control $(33.5 \pm 1.3 \mathrm{~kg} / \mathrm{d})(P=0.38)$.

In the present experiment, milk components affected by treatments, milk fat percentage, protein and ash content were significantly higher with experimental treatments compared with control. Whereas milk $\mathrm{pH}$ was significantly lower with experimental treatments compared with control. Other milk parameters were not affected by treatments. 
Table (2): Effect of Zn-Met. and Mn-Met. Supplementation of feeds on milk yield and milk composition lactating cows.

\begin{tabular}{|c|c|c|c|c|c|}
\hline \multirow{2}{*}{ Item } & \multicolumn{5}{|c|}{ Treatments $^{*}$} \\
\hline & $T_{1}$ & $\mathrm{~T}_{2}$ & $\mathbf{T}_{3}$ & $\mathbf{T}_{4}$ & $\pm \mathrm{SE}$ \\
\hline \multicolumn{6}{|l|}{ Milk yield kg/day } \\
\hline Week 3 to 12 & $34.5^{\mathrm{b}}$ & $36.9^{\mathrm{a}}$ & $36.2^{\mathrm{a}}$ & $36.6^{a}$ & \pm 1.1 \\
\hline Week 13 & $35.1^{\mathrm{b}}$ & $37.7^{\mathrm{a}}$ & $37.00^{a}$ & $37.2^{\mathrm{a}}$ & \pm 1.4 \\
\hline Week 14 & $35.5^{\mathrm{b}}$ & $37.9^{a}$ & $37.01^{a}$ & $37.39^{a}$ & \pm 1.4 \\
\hline $4 \% \mathrm{FCM}^{*}$ & $33.5^{\mathrm{b}}$ & $35.6^{\mathrm{a}}$ & $35.01^{a}$ & $35.30^{\mathrm{a}}$ & \pm 1.4 \\
\hline \multicolumn{6}{|c|}{ Milk composition (\%) } \\
\hline Total solids \% & $11.62^{b}$ & $11.94^{\mathrm{a}}$ & $11.82^{\mathrm{a}}$ & $11.92^{\mathrm{a}}$ & \pm 0.54 \\
\hline Solids not fat \% & $7.99^{b}$ & $8.20^{\mathrm{a}}$ & $8.09^{a}$ & $8.20^{\mathrm{a}}$ & \pm 0.25 \\
\hline Fat \% & $3.63^{b}$ & $3.74^{a}$ & $3.73^{\mathrm{a}}$ & $3.72^{\mathrm{a}}$ & \pm 0.28 \\
\hline Protein \% & $3.18^{b}$ & $3.32^{\mathrm{a}}$ & $3.22^{\mathrm{a}}$ & $3.29^{a}$ & \pm 0.16 \\
\hline Lactose \% & 4.25 & 4.25 & 4.25 & 4.25 & \pm 0.16 \\
\hline Ash \% & $1.08^{\mathrm{b}}$ & $1.13^{\mathrm{a}}$ & $1.12^{\mathrm{b}}$ & $1.14^{\mathrm{a}}$ & \pm 0.06 \\
\hline $\mathrm{pH}$ values & $6.77^{a}$ & $6.60^{b}$ & $6.65^{\mathrm{b}}$ & $6.65^{\mathrm{b}}$ & \pm 0.021 \\
\hline
\end{tabular}

a,b,...means with different superscripts in the same row or column within different significantly ( $P<0.05)$. *4\% FCM was calculated as: $0.4 \times$ milk yield $(\mathrm{kg})+15 \times$ fat yield $(\mathrm{kg})$ (Noeek. et al., 2006).

${ }^{\star} \mathrm{T}_{1}=$ Plain yoghurt made from milk produced from cows fed diets. $60 \%$ concentrate feed mixture $+20 \%$ berseemhay $+20 \%$ rice straw.

$\mathrm{T}_{2}=$ Control + $40 \mathrm{mg}$ Zinc- Methionin (Zn-Met.).

$\mathrm{T}_{3}=$ Control + $40 \mathrm{mg}$ Manganes - Methionin (Mn-Met.).

$\mathrm{T}_{4}=$ Control $+20 \mathrm{mg}$ (Mn-Met.) + $20 \mathrm{mg}$ (Zn-Met.).

Physicochemical determination:

Chemical composition of plain yoghurt:

Data of the composition of the plain yoghurt are summarized in Table (3).

Total fat, total protein and ash content of all plain yoghurt treatments made from milk produced from cows fed diets supplemented with different levels $\mathrm{Zn}$-Met. or Mn-Met. were not significantly affected as storage periods progressed (Table 3).

Table (3): Effect of experimental treatments and storage periods (days). on total fat, total protein and ash content of plain yoghurt.

\begin{tabular}{|l|c|c|c|c|c|}
\hline \multirow{2}{*}{ Treatment* $^{*}$} & \multicolumn{5}{|c|}{ Storage periods (days) } \\
\cline { 2 - 6 } & $\mathbf{0}$ & $\mathbf{3}$ & $\mathbf{7}$ & $\mathbf{1 0}$ & $\mathbf{1}$ SE \\
\cline { 2 - 6 } & \multicolumn{5}{|c|}{ Fat content \% } \\
\hline $\mathrm{T}_{1}$ & 3.0 & 3.0 & 3.0 & 3.0 & 0.029 \\
\hline $\mathrm{T}_{2}$ & 3.1 & 3.1 & 3.2 & 3.2 & 0.029 \\
\hline $\mathrm{T}_{3}$ & 3.0 & 3.0 & 3.1 & 3.1 & 0.029 \\
\hline $\mathrm{T}_{4}$ & 3.1 & 3.1 & 3.2 & 3.2 & 0.029 \\
\hline & \multicolumn{5}{|c|}{ Protein \% } \\
\hline $\mathrm{T}_{1}$ & 3.54 & 3.62 & 3.75 & 3.79 & 0.09 \\
\hline $\mathrm{T}_{2}$ & 3.46 & 3.52 & 3.61 & 3.78 & 0.09 \\
\hline $\mathrm{T}_{3}$ & 3.42 & 3.40 & 3.51 & 3.62 & 0.09 \\
\hline $\mathrm{T}_{4}$ & 3.44 & 3.55 & 3.66 & 3.70 & 0.09 \\
\hline \multicolumn{7}{|c|}{ Ash \% } \\
\hline $\mathrm{T}_{1}$ & 1.01 & 1.01 & 1.01 & 1.04 & 0.06 \\
\hline $\mathrm{T}_{2}$ & 1.04 & 1.04 & 1.06 & 1.09 & 0.06 \\
\hline $\mathrm{T}_{3}$ & 1.02 & 1.03 & 1.04 & 1.06 & 0.06 \\
\hline $\mathrm{T}_{4}$ & 1.03 & 1.03 & 1.05 & 1.07 & 0.06 \\
\hline
\end{tabular}

a,b,...means with different superscripts in the same row or column within different significantly $(P<0.05)$.

* See footnote Table (2). 
Total fat content in plain yoghurt treated was nearly similar to their control throughout the storage periods of 10 days. Similar results were reported by Badawi et al., (2008); Kebary et al., (2009).

Total protein and ash contents in plain of yoghurt treatments were not significant difference of fresh and during storage periods tended to slight increase as shown in Table (3). The apparent increase of protein is due to the increase of total solids because of the lose in moisture content.

Total solids of all plain yoghurt treatments made from milk produced form cows fed diets supplemented with different levels Zn-Met. or Mn-Met. were not significantly affected of fresh and throughout refrigerated storage periods till the 10 days. Table (4). No significant differences in their total solids of fresh and throughout the storage periods progressed $(P<0.05)$ tended to slight increase.

This increase may be attributed to the natural evaporation of moisture. Similar results were reported by A-assar et al., (2005).

For all Treatments as the storage period progressed, the lactose content gradually decreased because of the hydrolysis of lactose. On the other hand yoghurt produced from cows fed on supplemented feeds showed less content $(p<0.05)$ Table (4). This due to the effect of $\mathrm{Zn}$ or $\mathrm{Mn}$ supplementation on yoghurt bacterial growth. These results are in agreement with those reported (Degheide, 1998) and (Ezzat Abd El-Fattah et al., 2008).

Table (4): Effect of experimental treatments and storage periods (days) on total solids and lactose content of plain yoghurt.

\begin{tabular}{|c|c|c|c|c|c|}
\hline \multirow{3}{*}{ Treatment* } & \multicolumn{5}{|c|}{ Storage periods (days) } \\
\hline & Fresh & 3 & 7 & 10 & \pm SE \\
\hline & \multicolumn{5}{|c|}{ Total solids $\%$} \\
\hline $\mathrm{T}_{1}$ & 12.99 & 13.01 & 13.21 & 13.32 & 0.14 \\
\hline $\mathrm{T}_{2}$ & 12.89 & 12.92 & 12.92 & 12.94 & 0.14 \\
\hline $\mathrm{T}_{3}$ & 12.80 & 12.82 & 12.90 & 12.92 & 0.14 \\
\hline \multirow[t]{2}{*}{$\mathrm{T}_{4}$} & 12.84 & 12.89 & 12.92 & 12.93 & 0.14 \\
\hline & \multicolumn{5}{|c|}{ Lactose content $\%$} \\
\hline $\mathrm{T}_{1}$ & $4.21^{a}$ & $3.7^{b}$ & $3.4^{b}$ & $3.1^{\mathrm{bc}}$ & 0.06 \\
\hline $\mathrm{T}_{2}$ & $4.21^{\mathrm{a}}$ & $3.6^{b}$ & $3.4^{b}$ & $3.0^{c}$ & 0.06 \\
\hline $\mathrm{T}_{3}$ & $4.23^{\mathrm{ab}}$ & $3.6^{b}$ & $3.3^{b c}$ & $3.1^{b c}$ & 0.06 \\
\hline $\mathrm{T}_{4}$ & $40.22^{\mathrm{ab}}$ & $3.5^{b}$ & $3.2^{b c}$ & $3.0^{c}$ & 0.06 \\
\hline
\end{tabular}

a,b,...means with different superscripts in the same row or column within different significantly $(P<0.05)$.

* See footnote Table (2).

The apparent viscosity values are presented in Table (5). The highest viscosity values were in fresh plain yoghurt samples made from milk produced from cows fed diets supplemented with $40 \mathrm{mg} \mathrm{Zn}$-Met., followed by $20 \mathrm{mg} \mathrm{Zn}-\mathrm{Met}$ + $20 \mathrm{mg} \mathrm{Mn-Met}$ and then 40mg Mn-Met., as compared with control.

Whereas, throughout the storage periods values viscosity of plain yoghurt samples of treatments showed significant reduction $(P<0.001)$ till the end of storage, on contrast, control sample behaved in an opposite trend. 
These results may be attributed to the different nature of organic minerals and interaction between organic minerals and protein (Faten et al., 2010).

Table (5): Effect of experimental treatments and storage periods (days) on viscosity of plain yoghurt.

\begin{tabular}{|l|c|c|c|c|c|}
\hline \multirow{2}{*}{ Treatment $^{*}$} & \multicolumn{5}{|c|}{ Storage periods (days) } \\
\cline { 2 - 6 } & $\mathbf{0}$ & $\mathbf{3}$ & $\mathbf{7}$ & $\mathbf{1 0}$ & $\mathbf{1}$ \\
\cline { 2 - 6 } & \multicolumn{5}{|c|}{ Viscosity (poise) } \\
\hline $\mathrm{T}_{1}$ & $401^{\mathrm{d}}$ & $482^{\mathrm{cd}}$ & $601^{\mathrm{bc}}$ & $709^{\mathrm{a}}$ & 2.52 \\
\hline $\mathrm{T}_{2}$ & $785^{\mathrm{a}}$ & $644^{\mathrm{bc}}$ & $501^{\mathrm{c}}$ & $390^{\mathrm{e}}$ & 2.52 \\
\hline $\mathrm{T}_{3}$ & $569^{\mathrm{c}}$ & $537^{\mathrm{c}}$ & $502^{\mathrm{c}}$ & $390^{\mathrm{e}}$ & 2.52 \\
\hline $\mathrm{T}_{4}$ & $682^{\mathrm{b}}$ & $542^{\mathrm{c}}$ & $370^{\mathrm{e}}$ & $276^{\mathrm{f}}$ & 2.52 \\
\hline
\end{tabular}

$a, b, \ldots$ means with different superscripts in the same row or column within different significantly $(P<0.05)$.

* See footnote Table (2).

Data in Table (6) show the changes in titratable acidity and $\mathrm{pH}$ value of plain yoghurt treatments made from milk produced from cows fed diets supplemented with different levels Zn-Met., or Mn-Met., during storage. Results revealed that titratable acidity was significantly increased $(P<0.05)$ of all plain yoghurt treatments in fresh or during refrigerated storage periods compared with their control.

The highest rate of acid development was recorded in treatment with

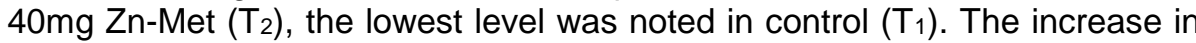
acidity could be due to the simulative acidic effect of trace elements (Zn-Met. or Mn-Met) on the growth and acid production by lactic acid bacteria which developing acidity throughout 10 days of storage and reduction of lactose content. These results are in agreement with those of Badawi et al., (2008), Farag et al., (2010) and Kebary et al., (2010). Conversely, pH values decline of all plain yoghurt samples during the storage periods Table (6).

Table (6): Effect of experimental treatments and storage periods (days) on titratable acidity and $\mathrm{pH}$ values of plain yoghurt.

\begin{tabular}{|l|c|c|c|c|c|}
\hline \multirow{3}{*}{ Treatment $^{*}$} & \multicolumn{5}{|c|}{ Storage period (days) } \\
\cline { 2 - 6 } & Fresh & $\mathbf{3}$ & $\mathbf{7}$ & $\mathbf{1 0}$ & $\mathbf{\pm}$ SE \\
\cline { 2 - 6 } & \multicolumn{5}{|c|}{ Acidity \% } \\
\hline $\mathrm{T}_{1}$ & $0.90^{\mathrm{f}}$ & $0.98^{\mathrm{de}}$ & $1.03^{\mathrm{d}}$ & $1.11^{\mathrm{bc}}$ & 0.008 \\
\hline $\mathrm{T}_{2}$ & $0.95^{\mathrm{e}}$ & $1.06^{\mathrm{c}}$ & $1.19^{\mathrm{b}}$ & $1.22^{\mathrm{a}}$ & 0.008 \\
\hline $\mathrm{T}_{3}$ & $0.92^{\mathrm{f}}$ & $1.01^{\mathrm{d}}$ & $1.09^{\mathrm{c}}$ & $1.18^{\mathrm{b}}$ & 0.008 \\
\hline $\mathrm{T}_{4}$ & $0.94^{\mathrm{e}}$ & $1.05^{\mathrm{c}}$ & $1.16^{\mathrm{b}}$ & $1.20^{\mathrm{a}}$ & 0.008 \\
\hline & \multicolumn{5}{|c|}{$\mathrm{pH}$ values } \\
\hline $\mathrm{T}_{1}$ & $4.78^{\mathrm{a}}$ & $4.72^{\mathrm{b}}$ & $4.69^{\mathrm{bc}}$ & $4.57^{\mathrm{d}}$ & 0.016 \\
\hline $\mathrm{T}_{2}$ & $4.64^{\mathrm{c}}$ & $4.60^{\mathrm{cd}}$ & $4.50^{\mathrm{d}}$ & $4.39^{\mathrm{g}}$ & 0.016 \\
\hline $\mathrm{T}_{3}$ & $4.69^{\mathrm{bc}}$ & $4.66^{\mathrm{bc}}$ & $4.51^{\mathrm{de}}$ & $4.49^{\mathrm{e}}$ & 0.016 \\
\hline $\mathrm{T}_{4}$ & $4.66^{\mathrm{bc}}$ & $4.61^{\mathrm{c}}$ & $4.58^{\mathrm{cd}}$ & $4.44^{\mathrm{f}}$ & 0.016 \\
\hline
\end{tabular}

a,b,...means with different superscripts in the same row or column within different significantly $(P<0.05)$.

* See footnote Table (2). 


\section{Rate of syneresis and curd tension:}

The syneresis (released whey) values are presented in Table (7). The use of organic trace minerals Zn-Met. or Mn-Met., or Zn + Mn-Met. In feeding cows, had significant decrease effect on the wheying off the amount of whey in fresh yoghurt and throughout storage period. These results are in accordance to those obtained by Mehanna and Hefnawy (1990); Mansoour et al., (1994) and Khalafalla and Roushdy (1996) when they reported that the effect of Zn-Met., or Mn-Met., during manufacturing plain yoghurt might enhance the water binding capacity of yoghurt coagulum thereby influencing the rate of synersis characteristics.

Conversely, curd tension results revealed an opposite trend of the rate of synersis value Table (7). Curd tension values of all plain yoghurt treatments had significant increased effect compared with their control in fresh or throughout storage periods.

The highest values were with $40 \mathrm{mg} Z \mathrm{n}$-Met. $\left(\mathrm{T}_{2}\right)$ followed by $20 \mathrm{mg}$ Zn-Met. +20 mg Mn-Met., ( $\left.T_{4}\right)$ and then $40 \mathrm{mg}$ Mn-Met. $\left(T_{3}\right)$.

Table (7): Syneresis and curd tension of yoghurt as affected by the type of feeds.

\begin{tabular}{|c|c|c|c|c|c|}
\hline \multirow{3}{*}{ Treatment* } & \multicolumn{5}{|c|}{ Storage periods (days) } \\
\hline & Fresh & 3 & 7 & 10 & \pm SE \\
\hline & \multicolumn{5}{|c|}{ Rate synersis (ml) } \\
\hline $\mathrm{T}_{1}$ & $27^{d}$ & $33^{c}$ & $39^{b}$ & $43^{a}$ & 2.08 \\
\hline $\mathrm{T}_{2}$ & $24^{\mathrm{de}}$ & $30^{\mathrm{cd}}$ & $35^{\mathrm{bc}}$ & $37^{b}$ & 2.08 \\
\hline $\mathrm{T}_{3}$ & $22^{e}$ & $26^{d}$ & $33^{c}$ & $35^{\text {be }}$ & 2.08 \\
\hline \multirow[t]{2}{*}{$\mathrm{T}_{4}$} & $22^{e}$ & $27^{d}$ & $33^{c}$ & $35^{\mathrm{bc}}$ & 2.08 \\
\hline & \multicolumn{5}{|c|}{ Curd tension (gm) } \\
\hline $\mathrm{T}_{1}$ & $16.93^{\mathrm{e}}$ & $16.98^{\mathrm{e}}$ & $17.01^{\mathrm{e}}$ & $17.09^{\mathrm{e}}$ & 0.18 \\
\hline $\mathrm{T}_{2}$ & $20.22^{a}$ & $19.95^{b}$ & $19.97^{b}$ & $19.77^{b}$ & 0.18 \\
\hline $\mathrm{T}_{3}$ & $18.84^{d}$ & $18.89^{d}$ & $19.03^{c}$ & $19.09^{c}$ & 0.18 \\
\hline $\mathrm{T}_{4}$ & $18.89^{\mathrm{c}}$ & $18.93^{c}$ & $19.07^{\mathrm{c}}$ & $19.23^{c}$ & 0.18 \\
\hline
\end{tabular}

a,b,...means with different superscripts in the same row or column within different significantly $(P<0.05)$.

* See footnote Table (2).

\section{Incubation time:}

Data in Table (8) show that the incubation time values of plain yoghurt milk treatments or control, which recorded the lowest $\mathrm{pH}$ value 4.6 and decreased the time $(150 \mathrm{~min})$ with treatment with $40 \mathrm{mg} \mathrm{Zn-Met.}\left(\mathrm{T}_{2}\right)$. followed by treatment with $20 \mathrm{mg} \mathrm{Zn}+20 \mathrm{mg} \mathrm{Mn}\left(\mathrm{T}_{4}\right)$ and then treatment with $40 \mathrm{mg} \mathrm{Mn}$ Met. $\left(T_{3}\right)$ compared with control $\left(T_{1}\right)$, which recorded pH4.6 after (180 min). Table (8). These obtained results revealed that the incubation effect of $\mathrm{Zn}$-Met., on the microorganism of plain yoghurt was stronger than that of Mn., (Momeilovic and Kello, 1979); (Vak et al., 1989). 
Table (8): Effect of experimental treatments on the $\mathrm{pH}$ values during incubation time (minutes) of plain yoghurt.

\begin{tabular}{|c|c|c|c|c|c|c|c|}
\hline \multirow{3}{*}{ Treatment $^{\star}$} & \multicolumn{7}{|c|}{ Incubation Time (minutes) } \\
\hline & 0 & 30 & 60 & 90 & 120 & 150 & 180 \\
\hline & \multicolumn{7}{|c|}{ pH values } \\
\hline $\mathrm{T}_{1}$ & 6.63 & 6.43 & 6.25 & 5.80 & 5.69 & 5.45 & 4.64 \\
\hline $\mathrm{T}_{2}$ & 6.60 & 6.07 & 5.70 & 5.32 & 4.96 & 4.60 & $=$ \\
\hline $\mathrm{T}_{3}$ & 6.62 & 6.22 & 5.80 & 5.39 & 4.86 & 4.72 & 4.63 \\
\hline $\mathrm{T}_{4}$ & 6.60 & 6.21 & 5.69 & 5.20 & 4.86 & 4.69 & $=$ \\
\hline
\end{tabular}

a,b,...means with different superscripts in the same row or column within different significantly $(P<0.05)$.

* See footnote Table (2).

= not estimated

\section{Distribution of organic minerals:}

Table (9) shows the distribution of zinc ( $\mathrm{Zn})$ and manganese $(\mathrm{Mn})$ in different treatments between analyzed milk from cows, plain yoghurt and whey. From these results it could be noted that the association of $\mathrm{Zn}$ or $\mathrm{Mn}$ in analyzed milk, plain yoghurt curd and whey were not the same for different treatments. These values revealed that the average contents of $\mathrm{Mn}$ in analysed milk were $(25.09,27.01,34.0,32.0 \mu \mathrm{g} / \mathrm{kg})$ for $\mathrm{T}_{1}, \mathrm{~T}_{2}, \mathrm{~T}_{3}$, and $\mathrm{T}_{4}$ respectively. higher contents of $\mathrm{Mn}$ in analyzed milk were observed by (Zapletal and Bon czar, 1993) $36.8 \mu \mathrm{g} / \mathrm{kg}$. Also, the ratio of $\mathrm{Mn}-\mathrm{Met}$. bound to the casein fraction in pellet plain yoghurt significant increased $(P<0.01)$. (Table, 9) whereas, the ratio of $M n$ bound to the whey significant decreased $(P<0.05)$. this could be due to the $M n$ which is very strongly bound to organic matter. These results are in the line with that reported by Abollino et al., (1998) who found that, manganese is mainly distributed between the serum of cationic and the casein-bound fraction, probably associated with some enzymes or other proteins and stated that about $53.7 \%$ of $\mathrm{Mn}$ was bound to casein while $44.7 \%$ of $\mathrm{Mn}$ was in the whey.

Considering, the concentration of $\mathrm{Zn}$ in analyzed milk in different treatments. It was that the average contents of $\mathrm{Zn}$ in analyzed milk produced from cows fed diets supplemented with $Z n-M e t$. were $3.7 \pm 0.1 \mathrm{mg} / \mathrm{kg}^{-1}$ and were similar to $\mathrm{Zn}$ concentration of $3.73 \mathrm{mg} / \mathrm{kg}^{-1}$ fresh milk. by (Szkoda and Zmudzki (2002)). Higher contents of Zn in milk rang of 4.1 to $5.28 \mathrm{mg} / \mathrm{kg}^{-1}$, by (Rodrigues et al., 2001). While, in pellet plain yoghurt the ratio of $\mathrm{Zn}$ bound to whey significant increased $(P<0.01)$. (Table,9). Conversely, the ratio of $Z n$ bound to the casein fraction significant decreased $(P<0.01)$. these results are in agreement with those of Singh, et al., (1989) and Pabon and Lonnerdal (2000) reported that the most of $\mathrm{Zn}$ directly bound to casein is readily removed when $\mathrm{pH}$ decreased to low values this is due to high levels of soluble $\mathrm{Zn}$ bound to low molecular weight and non micellar- $\mathrm{Zn}$ levels increased. 
Table (9): Distribution of $\mathrm{Zn}$ and $\mathrm{Mn}$ in analyzed milk, plain yoghurt curd and whey after 7 days .

\begin{tabular}{|c|c|c|c|}
\hline Treatment $^{*}$ & Analyzed milk & Plain yoghurt & Whey \\
\hline \multicolumn{4}{|c|}{$\mathrm{Zn}(\mathrm{mg} / \mathrm{kg})$} \\
\hline$\left(T_{1}\right)$ & 3.70 & $43.32^{b}$ & $56.68^{a}$ \\
\hline$\left(T_{2}\right)$ & 3.92 & $40.75^{b}$ & $59.25^{a}$ \\
\hline$\left(T_{3}\right)$ & 3.75 & $46.09^{b}$ & $53.91^{a}$ \\
\hline$\left(\mathrm{T}_{4}\right)$ & 3.87 & $42.55^{b}$ & $57.45^{a}$ \\
\hline \multicolumn{4}{|c|}{ Mn. $(\mu \mathrm{g} / \mathrm{kg})$} \\
\hline$\left(\mathrm{T}_{1}\right)$ & 25.09 & $45.09^{b}$ & $54.91^{\mathrm{a}}$ \\
\hline$\left(T_{2}\right)$ & 27.01 & $57.32^{\mathrm{a}}$ & $42.68^{b}$ \\
\hline$\left(T_{3}\right)$ & 34.00 & $68.57^{a}$ & $31.43^{b}$ \\
\hline$\left(T_{4}\right)$ & 32.00 & $57.64^{a}$ & $42.36^{b}$ \\
\hline
\end{tabular}

$a, b, \ldots$ means with different superscripts in the same row or column within different significantly $(P<0.05)$.

* See footnote Table (2).

\section{Sensory evaluation:}

Results in Table (10) showed the changes in sensory evaluation of fresh or stored yoghurt samples made from milk produced from cows fed diets supplemented with different levels Zn-Met., or Mn-Met., Form these results it could be noted that the sensory properties of plain yoghurt were significantly affected $(P<0.05)$ by Zn-Met., or Mn-Met., throughout storage periods.

No dectable changes were observed in color and taste of fresh or stored samples which gained 8:10 points.

Table (10) shows significant differences in the scores for flavour and body and texture received from different treatments of fresh or stored plain yoghurt. Samples of plain yoghurt treatments with $40 \mathrm{mg} \mathrm{Zn}$-Met., $\left(\mathrm{T}_{2}\right)$ had significant increased in scores flavour, body and texture compared with control and other treatments.

Total acceptability points revealed that samples of plain yoghurt made from milk produced from cows fed diets supplemented with 40mg Mn-Met., had been recorded weak body and wheying off increase the amount of whey. Whereas, samples of plain yoghurt treatment with $40 \mathrm{mg} \mathrm{Zn}-$ Met., had been recorded the highest points for their acceptable flavour, body and texture and no wheying off up to 7 days of storage and then decreased after that. Table (10). These results are in agreement with (Kebary et al., 2008 and Kebary et al., 2010). 
Table (10): Sensory evaluation of plain yoghurt made from different milks through storage periods (days) $6 \pm 1^{\circ} \mathrm{C}$.

\begin{tabular}{|c|c|c|c|c|}
\hline \multirow{3}{*}{ Treatment* } & \multicolumn{4}{|c|}{ Storage period (days) } \\
\hline & 0 & 3 & 7 & 10 \\
\hline & \multicolumn{4}{|c|}{ Color and Appearance (10) } \\
\hline $\mathrm{T}_{1}$ & $10^{\mathrm{a}}$ & $9^{a}$ & $9^{a}$ & $8^{b}$ \\
\hline $\mathrm{T}_{2}$ & $10^{\mathrm{a}}$ & $10^{\mathrm{a}}$ & $10^{\mathrm{a}}$ & $9^{a}$ \\
\hline $\mathrm{T}_{3}$ & $10^{\mathrm{a}}$ & $9^{a}$ & $9^{a}$ & $8^{b}$ \\
\hline $\mathrm{T}_{4}$ & $10^{\mathrm{a}}$ & $8^{b}$ & $8^{b}$ & $8^{b}$ \\
\hline \multicolumn{5}{|c|}{ Body and Texture (40) } \\
\hline $\mathrm{T}_{1}$ & $40^{a}$ & $38^{b}$ & $38^{b}$ & $37^{b}$ \\
\hline $\mathrm{T}_{2}$ & $40^{\mathrm{a}}$ & $39^{b}$ & $39^{b}$ & $38^{b}$ \\
\hline $\mathrm{T}_{3}$ & $40^{\mathrm{a}}$ & $33^{c}$ & $32^{c}$ & $32^{c}$ \\
\hline $\mathrm{T}_{4}$ & $40^{\mathrm{a}}$ & $38^{b}$ & $35^{c}$ & $35^{c}$ \\
\hline \multicolumn{5}{|c|}{ Flavour (50) } \\
\hline $\mathrm{T}_{1}$ & $48^{a}$ & $45^{b}$ & $44^{b}$ & $44^{b}$ \\
\hline $\mathrm{T}_{2}$ & $48^{a}$ & $47^{a}$ & $45^{b}$ & $45^{b}$ \\
\hline $\mathrm{T}_{3}$ & $47^{a}$ & $40^{c}$ & $35^{a}$ & $35^{d}$ \\
\hline $\mathrm{T}_{4}$ & $40^{c}$ & $38^{c}$ & $37^{c}$ & $40^{c}$ \\
\hline \multicolumn{5}{|c|}{ Total score (100) } \\
\hline $\mathrm{T}_{1}$ & $98^{a}$ & $92^{b}$ & $90^{c}$ & $89^{c}$ \\
\hline $\mathrm{T}_{2}$ & $98^{a}$ & $96^{a}$ & $93^{b}$ & $92^{b}$ \\
\hline $\mathrm{T}_{3}$ & $97^{\mathrm{a}}$ & $82^{b}$ & $76^{c}$ & $75^{c}$ \\
\hline $\mathrm{T}_{4}$ & $97^{a}$ & $87^{b}$ & $81^{c}$ & $80^{d}$ \\
\hline
\end{tabular}

\section{CONCLUSIONS}

From these results, it could be concluded that zinc or Manganese methionine supplementation at the level of $40 \mathrm{mg}$ per head daily to lactating cows improved the quality, yield of the milk and it's components. When the level of zinc or Manganese in diets plain yoghurt had relatively high Zinc retention. They improved acidic effect of trace minerals on the growth and acid production by lactic acid bacteria throughout 10 days of storage and reduction of lactose content, decreased the time for incubation period, less wheying off, and gained the highest scoring points for their acceptable flavour, body and texture.

Generally, this increase could be significant if these products were included in a daily diet. Therefore, the need for increasing these minerals in raw milk could be recommended.

\section{REFERENCES}

A. O. A. C. Official Methods of Analysis Association official Analytical Chemists,. (2000), 17 th Ed. Washington, Dc, USA.

Abollino, O., Accto, M., Bruzzoniti, Mc., Mentasti, E. and sarzanini, C. (1998). Speciation of copper and manganese in milk by solid-phase extraction inductivel, coupled plasma-atomic emission spectrometry Analyica chimica Acta 375: 299-306. 
Achanta, K., Aryana, J. K. and Boenke, C. A. 2007. Fat free plain set yoghurts forlitied with various minerals. LWT 40: 424-429.

Al-Assar M. A., El-Abd M. M., El-sabie W. B., Attia M. (2005). Characteristics of low cholesterol Rayeb milk during storage. Egypt. J. Appl. Sci., 20 (5) $739-750$.

Badawi, R. M.; Hamed, A. L.; Kebary, K. M. K. and El-sayed, H. A. (2008). Effect of replacing milk fat with fat replacers on the quality of stirred yoghurt. Egypt. J. Dairy Sci., 36: 197.

Bailery, J.D. R. P. Ansotegui, J. A. Paterson, C.K. Swenson and A.B. Johnson, "Effects of supplementing Combinations of Inorganic and Complexed Copper on performance and liver Mineral status of Beef Heifers Consuming Antagonists "Journal of Animal science, Vol.79, No. 11, 2001, pp. 2926-2934.

Bernett, A. J. G. and Abdel-Tawab, G. (1957). Arapid method for the determination of lactose in milk and cheese. J. Food Sci. Agric. 8: 437441.

Cvak, Z., Erban, V., Obermair, O. and Jicinska, E. (1989). Effect of milk concentration with heavy metals ions on dairy cultures. I. Cadmium, Copper, lead, Mercury, Zinc. Ceskoslovenska. Hygiena 34: (1) 18-27.

Deal-P-Van; Shen, L. H.; Deelstra, H. (1993). In influence of milk processing on the in vitro availability on Zinc and selenium from milk. Bioavailability Nutrional, Chemical and Food Processing Implications of Nutrient Availability. Part 1, pp. 322-325. Milk and Dairy products.

Degheid, M. A. (1998). Influence of enriching yoghurt with Zinc sulphate on some chemical and physic-Chemical properties during storage. J. Agric, Sci., Mansoura Univ., 23: 6099.

Duncan, D.B. (1955). Multiple rang and multiple F. test. Biometrics, 11: 1-42.

Ezzat Abd El-Fattah Mohamed Ahmed. (2008). Astudy on effect of mineral content of milk and milk products on nutritive value. Ph. D thesis, faculty of Agriculture Al-Azhar University.

Faten lotfi Selet., Wagih I. El-K, and Nabil. S. A. (2010). Evaluation of milk drink produced by probiotic bacteria and fortified with Zinc salts. (accepted, under publication). Polish Journal of food and Nutrition scences, 2011, Vol. 61, No.1.

Formigoni, A., P. Parisini, and F. Corradi. 1993. the use of amino acid chelates in high production milk cows. Pages. 170-186 in the Roles of Amino Acid Chelates in Animal Nutrition. H. D. Ashmead, ed. Noyes publ., Park Ridge, NJ.

Jarrstt, W.D. (1979). Areview of the important trace elements in dairy products. The Australian Journal of Dairy Techology. No. (3), P.28.

Jayasekarel, S., U. Samarajeewa and A. N. Jayakody (1992). Trace metals in food and animals origin in srilanka. Asian. Food J., 7: 105-107.

Kebary, K. M. K. and S. A. Hussein (1999). Monufacture of low fat zabady using different fat substitutes Acta Alimentatia 28: 1-16.

Kebary, K. M. K.; Badawi, R. M.; Hamed, A. I. and Omar, N. S. (2010). Preparation and properties of novel functional yoghurt from buffalo milk. Proc. $11^{\text {th }}$ Egyptian conf. Dairy Sci. and Technolo. PP. 463-478. 
Kebary, K. M. K.; El-Sonbaty, A. H.; Zedan, A. N. and El-sayed, H. A. (2008). Impact of bifidobacteria on flavoured low fat stirred yoghurt quality. Proc. $3^{\text {rd }}$ Int. conf. food sci. \& Nutr., Cairo, Egypt, pp. 160-179.

Kebary, K. M. K.; Hamed, A. I.; Badran, I.I.; Hussein, S. A. and Gaber, A. M. (2009). Manufacture of yoghurt from cow's milk fortified with trypsin modified whey proteins. Minufiya J. Agric. Res. 34: 1525.

Khalafalla, S. M. and Roushdy, I. M. (1996). Effect of stabilizers on rheological and sensory properties of low fat buffaloe's yoghurt Egypt. J. Food Sci., 24 (2): 199.

Ling, E. R. (1263). Test Book of Daily chemistry. Vol. 2, Partical $3^{\text {rd }}$ Ed. Chapman and Hall Itd., London.

Maret W, Sandstead HH. (2006). Zinc requirements and the risks and benefits of Zinc supplementation J trace Elem Med Biol.; 20: 3-18. [Pub Med Abstract].

Miles, R. D., Henry, P.R., 1999. Relative trace mineral bioavailability. In proceedings of the California Animal Nutration Conference held on May 5 and 6, 1999, Piccadilli Inn-Hotels, Fresno, CA, pp.1-24.

Momeilovic, B. and kello, D. (1979). Fortification of milk with Zinc and Iron. Nutrition reports International 20 (3): 436-Cited from Sci Techn. Abs 1979.

Nielsen, F. H. (1994). Ultratrace minerals. In: M. E. shills, J. A. Olson, M. shike (Eds), Modern nutrition in health and disease (Vol. 1, $8^{\text {th }}$ ed., pp. 269-286). Philadelphia: Lea \& Febigery.

Noeek, J. E., Socha, M. T. and D. J. Tomlinson "The Effect of trace Mineral fortification level and source on performance of Dairy cattle" Journal of Dairy Science, Vol. 89, No. 7, 2006. PP. 2679-2693.

NRC. 2001. Nutrient Requirements of Dairy Cattle. $7^{\text {th }}$ rev. ed. Natl. Acad. Sci., Washington, DC.

Pabon, M.L. and Lonnerdal, B. (2000). Bioavailability of Zinc and its binding to casein in milks and formulas. Journal of trace Elements Med. Biol. 14: 146-153.

Rodriguez E M, Sanz Alaejos M, Diaz Romero, C. (2001). Mineral concentrations in cow's milk from the Canary Island. of Food Comp and Anal 14: 419-430.

SAS, (1996). User's Guide: Statistics, version 6.12 Edition. SAS Inst. Inc., Cary, NC, U.S.A.

Singh, H., Flynn, A. and Fox, P. F. (1989). Zinc binding in bovine milk. Journal of Dairy Research 56: 249-263.

Szkoda J. Zmudzki J. (2002). Zinc in animal tissues and food of animal origin. Zesz Nauk polish Acad Sci 33: 457-463. (in polish with English abstract).

Tamime, A. R. and Death, H. C. (1980). Roghurt: Technology and Biochemistry J. Food protection. 43: 939.

Tamime, A. R. and R. K. Robinson (1999). Roghurt science and technology. Cambridge, Uk: woodhead publishing Ltd.

Ward, J.O. J.W. spears and E.B. Kegley, "Bioavailability of Copper proteinate and Copper carbonate Relative to Copper Sulfate in Cattle" Journal of Dairy Science, Vol. 79, No.1, 1996, pp. 127-132. 
Zapletal P, Bonczar G. (1993). The content of minerals and som trace elements in raw milk from Krakow area. Przegl Mlecz 11: 298-300 (in polish).

Zin, Z, D.F. Waterman, R. W. Neinken and R. J. Harmon, "Copper Status and Requirement during the Dry period and Early Lactation in Multiparous Holstein cows", Journal of Dairy science, Vol. 76, No. 9, 1993, PP. 2711-2716.

تأثير إضافة الزنك والمنجنيز المرتبط كل منهمـا بـالمثيونين إلى علائق الأبقار على إنتاج وصفات اللبن و بعض منتجاته. أمل مجاهد محمد النمر' ومحمد على أحمد' وحاتم حلمى عمر' ومحمود عبد العزيز يوسف المنياوى

1- ق قسم بحوث تكنولوجيا الألبان - معه بحوث الإنتاج الحيواني ـ مركز البحوث الزراعية ـ

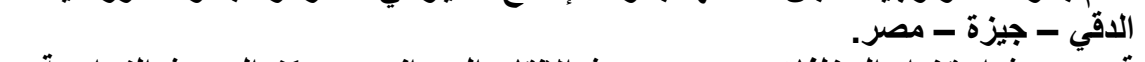

r - قسم بحوث استخدام المخلفات ـ معهة بحوث الإنتاج الحيوانى ـ مركز البحوث الزراعية ـ

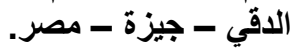

تهدف الدراسة إلى نأثير إضافة الزناف و المنجنيز المرتبط كل منهما بالمثيونين إلى علائق

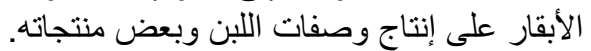

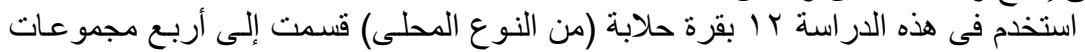

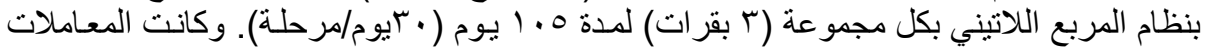
كالتالي:-

ا - ألمعاملة الأولي (المقارنة):غذيت على مقررات NRC 2001 و تتنكون من علف مركز +

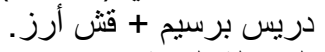

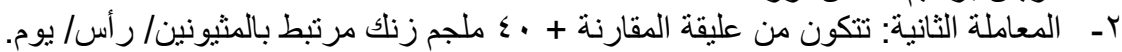

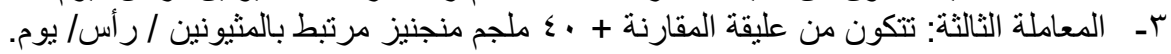

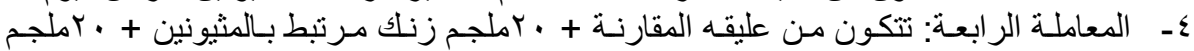

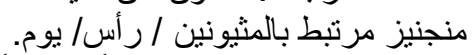

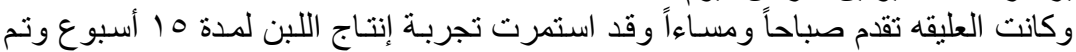

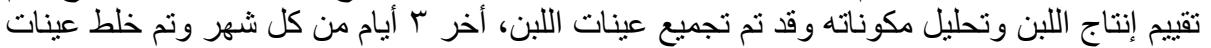

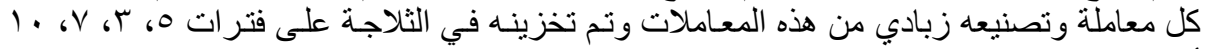

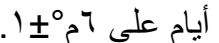

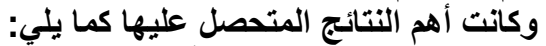

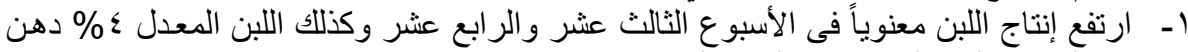

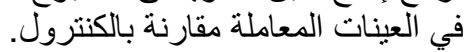

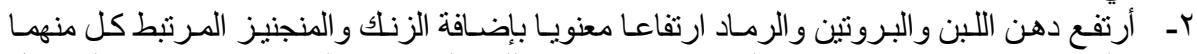

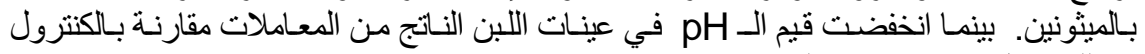

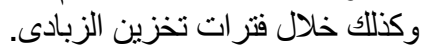

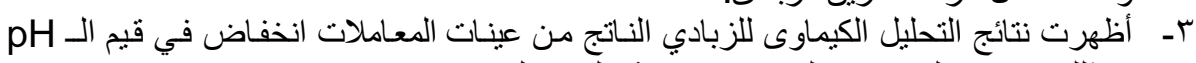

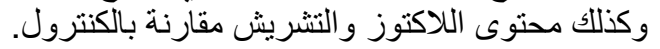

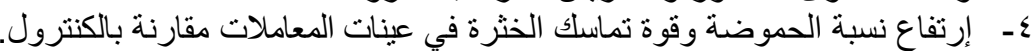

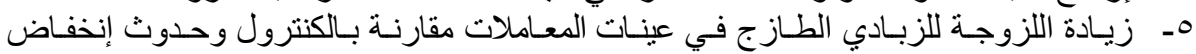

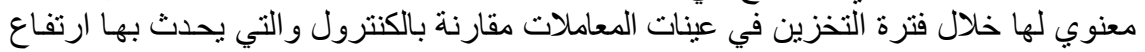

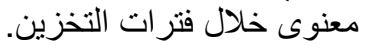




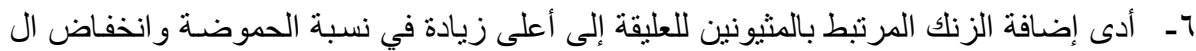

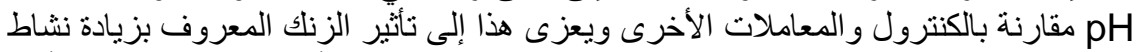

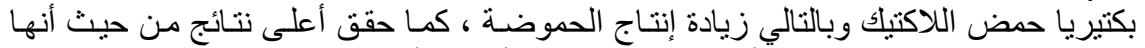

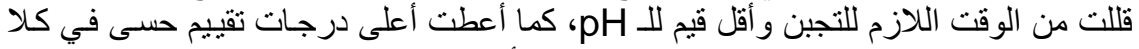

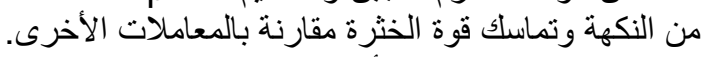

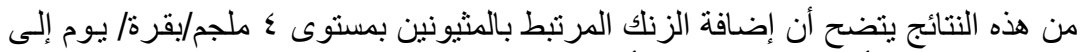

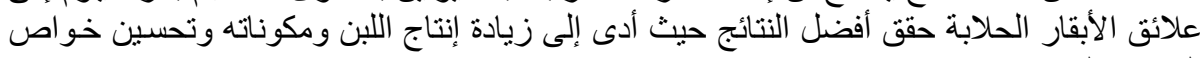

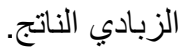

كلية الزراعة - جامعة المنصورة قام بتحكيم البحث

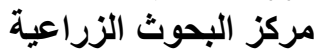

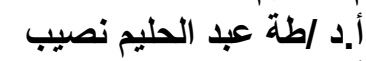
أ.د أد إطيى عبد الهيم عبد القادر 